\title{
RECENT ADVANCES IN POLYPHENOLS NANOCARRIERS AGAINST BREAST CANCER THERAPY FOCUS ON IN VITRO STUDIES: LITERATURE REVIEW ${ }^{1}$
}

\author{
AVANÇOS RECENTES EM NANOCARREADORES DE POLIFENÓIS \\ CONTRA TERAPIA DO CANCER DE MAMA FOCO EM ESTUDOS IN VITRO: \\ REVISÃO DE LITERATURA
}

\author{
Mariana Fernandes Ribeiro ${ }^{2}$, Francine Carla Cadoná ${ }^{3}$ e Patrícia Gomes ${ }^{4}$
}

\begin{abstract}
Cancer is considered a severe public health problem worldwide. Among the most incident cases, breast cancer, which affects many women in the entire world, can be mentioned. Currently, there are well-established protocols for the treatment of this type of cancer. However, cancer treatment presents collateral effects that can compromise the patient's quality of life. Therefore, studies have suggested that plants and fruits rich in polyphenols have antitumor activity, decrease chemotherapy resistance, and reduce side effects caused by chemotherapy. However, most of these compounds have low bioavailability making their potential pharmacological challenging. Therefore, the search for carriers that can efficiently protect and transport these bioatives to tumor cells is of great interest. In this sense, nanostructured systems can be included as the delivery of bioactive molecules and drugs. Thus, this study aimed to report the current studies using nanocarriers containing phenolic compounds to evaluate their antitumor effect against breast cancer cells. Data collection included the virtual databases Science Direct and Web of Science using the descriptors: nanoparticles and polyphenols and breast cancer, for experimental articles published from 2015 to September 15, 2020. The search resulted in a total of 1346 articles, of 37 met the inclusion criteria. The studies have demonstrated the efficiency of nanostructures containing polyphenols against cancer cells, suggesting excellent perspectives in the use of nanotechnology combined with bioactive compounds in the treatment of breast cancer.
\end{abstract}

Keywords: Anticancer activity, Nanotechnology, Phenolic compounds.

\section{RESUMO}

O câncer é considerado um grave problema de saúde pública em todo o mundo. Entre os casos mais incidentes, pode-se citar o câncer de mama, que atinge muitas mulheres em todo o mundo. Atualmente, existem protocolos bem estabelecidos para o tratamento desse tipo de câncer. No entanto, o tratamento do câncer apresenta efeitos colaterais que podem comprometer a qualidade de vida do paciente. Portanto, estudos têm sugerido que plantas e frutas ricas em polifenóis têm atividade antitumoral, diminuem a resistência à quimioterapia e reduzem os efeitos colaterais causados pela quimioterapia. No entanto, a maioria desses compostos tem baixa biodisponibilidade, tornando seu potencial desafio farmacológico. Portanto, a busca por carreadores que possam proteger e transportar de forma eficiente esses bioativos para as células tumorais é de grande interesse. Nesse sentido, os sistemas nanoestruturados podem ser incluídos como a entrega de moléculas bioativas e fármacos. Assim, este trabalho teve como objetivo relatar os estudos atuais utilizando nanocarreadores contendo compostos fenólicos para avaliar seu efeito antitumoral contra células de câncer ${ }^{1}$ Study performed at Nanosciences Posgraduate Program.

${ }^{2}$ Student of the Nanosciences Posgraduate Program - Universidade Franciscana. E-mail: mariana.ribeiro@ufn.edu.br

${ }^{3}$ Teacher of the Health and life sciences Posgraduate Program - Universidade Franciscana. E-mail: f.cadona@ufn.edu.br

${ }^{4}$ Teacher of the Nanosciences Posgraduate Program -Universidade Franciscana. E-mail: patriciagomes@ufn.edu.br 
de mama. A coleta de dados incluiu as bases de dados virtuais Science Direct e Web of Science utilizando os descritores: nanopartículas e polifenóis e câncer de mama, para artigos experimentais publicados de 2015 a 15 de setembro de 2020. A busca resultou em um total de 1.346 artigos, dos quais 37 atenderam à inclusão critério. Os estudos demonstraram a eficiência de nanoestruturas contendo polifenóis contra células cancerosas, sugerindo excelentes perspectivas no uso da nanotecnologia combinada com compostos bioativos no tratamento do câncer de mama.

Palavras-chave: Atividade anticâncer, Nanotecnologia, Compostos fenólicos.

\section{INTRODUCTION}

Breast cancer is the most commonly diagnosed neoplasm worldwide, being the leading cause of cancer death in women. According to estimates by the National Cancer Institute (INCA) the estimated number of incident breast cancer cases in Brazil, for 2020, was 66,280 for each year of the 2020-2022 triennium. The incidence of this pathology comes persistently due to several genetic and environmental factors such as eating habits, physical inactivity, radiation exposure, hormonal therapy, alcohol consumption, cases of cancer in the family, among others (KOLAK et al., 2017). Currently, treatment for breast cancer can be classified as systemic, radical, or conservative. Among the protocols used in treatments includes hormonal or cytotoxic chemotherapy, immunotherapy, surgery, and radiotherapy. However, one of the main problems associated with cancer treatment is the toxic side effect. Most chemotherapeutic agents used cannot differentiate between normal and tumor cells and induce cell death in all cells that present a rapid proliferation (RAMLJAK et al., 2005).

In search of compounds that can be efficient with low or no adverse effects, the pharmaceutical industry is continuously investigating natural products to prevent and treat cancer (SILVA et al., 2019). Polyphenols are one of the most numerous and widely distributed groups of natural products. Research on polyphenols in the diet has shown positive results by reducing several chronic diseases, including cancer. Some studies reported antioxidant, anti-inflammatory, and antimicrobial effects (KHAN et al., 2019). Different mechanisms have been suggested to explain the anticancer effects of phenolic compounds, such as, for example, acting as suppressive agents that inhibit the formation and growth of tumors, inhibiting proliferation offering better preventive and therapeutic options.

However, the low solubility, rapid metabolism, and low gastrointestinal absorption of polyphenols used in the diet are significant obstacles to their pharmacological potential (KHAN et al., 2019). To overcome the polyphenols bioavailability problem and improve the pharmacokinetics, several methodologies have been proposed for the encapsulation of these compounds, generating more stable forms of delivery. Nanostructures are one of the main options for being a delivery system for bioactive compounds, offering advantages such as protection against degradation, interaction with the biological environment, better absorption, retention time, controlled delivery, among other 
benefits (SANTOS et al., 2019). Through the targeted administration of drugs through nanoformulations, better administration of the tumor site, and better therapeutic responses can reduce side effects. Besides, there is an increase in cell selectivity reducing the adverse effects caused by conventional chemotherapy, showing that nanotechnology may be able to overcome the limitations of polyphenols, causing promising results in the treatment of cancer (DAVATGARAN-TAGHIPOUR et al., 2017; PEREZ -RUIZ et al., 2018). This study aims to review available data on nanoformulations containing natural polyphenols as chemopreventive and chemotherapeutic agents and discuss anticancer action mechanisms in recent years.

\section{MATERIALS AND METHODS}

This study is a systematic literature review. The search for work publications happened from January to September 2020 through the electronic databases: Science Direct and Web of Science. The descriptors used for this review were: nanoparticles and polyphenols, and breast cancer, with articles published from 2015 to September 15, 2020. The inclusion criteria used to select the items were: article-type publications with texts in the English language. The exclusion criteria were publications whose central theme did not match the research, literature review studies, book chapters, and other works that did not correspond to experimental studies.

The search in the databases resulted in 1346 articles, of which 37 met the proposed criteria. Figure 1 shows the flowchart for the selection of items in the databases.

Figure 1 - Flowchart representing the search for articles in the databases according to the established criteria.

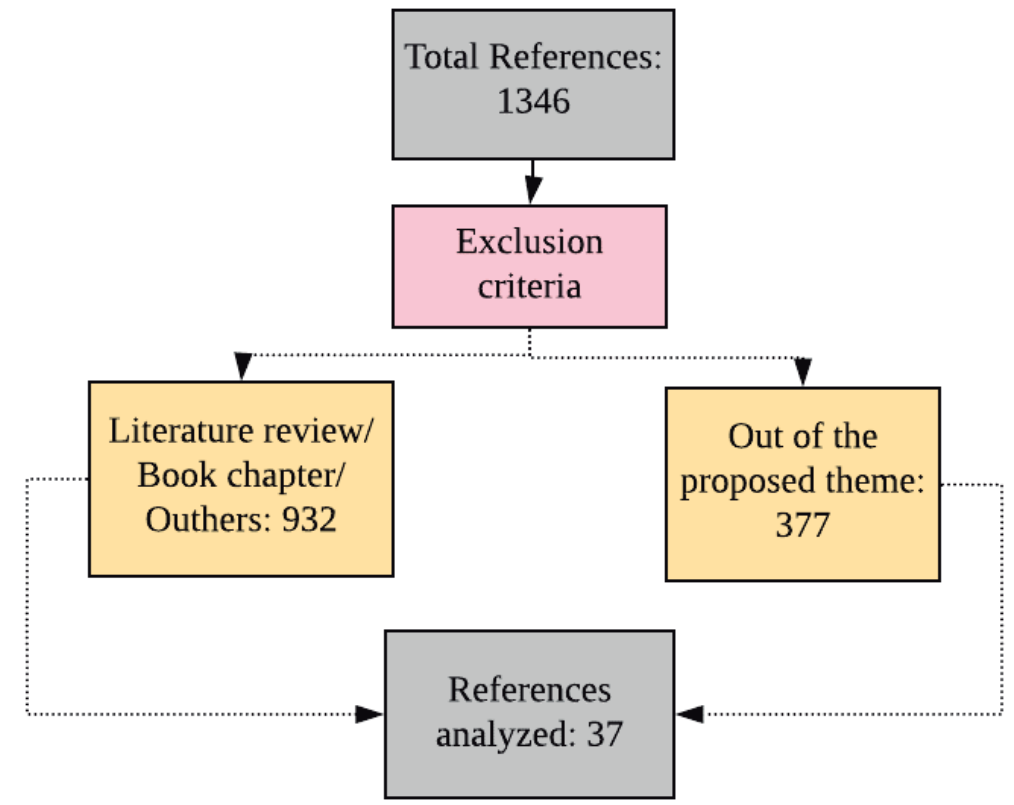

Source: Author's construction. 


\section{RESULTS AND DISCUSSIONS}

According to the chemical structure, polyphenols are classified into flavonoids, phenolic acids, stilbenes, lignans, curcuminoids, and tannins, as illustrated by some examples in the figure below (MOJZER et al., 2016) (Figure 2). Many of these compounds have been found in the literature as a primary or adjuvant asset with chemotherapy drugs evaluating their cytotoxic potential in vitro studies against different lines of breast cancer cells (AVTANSKI, PORETSKY, 2018).

Figure 2 - Flowchart representing the main classes of polyphenols.

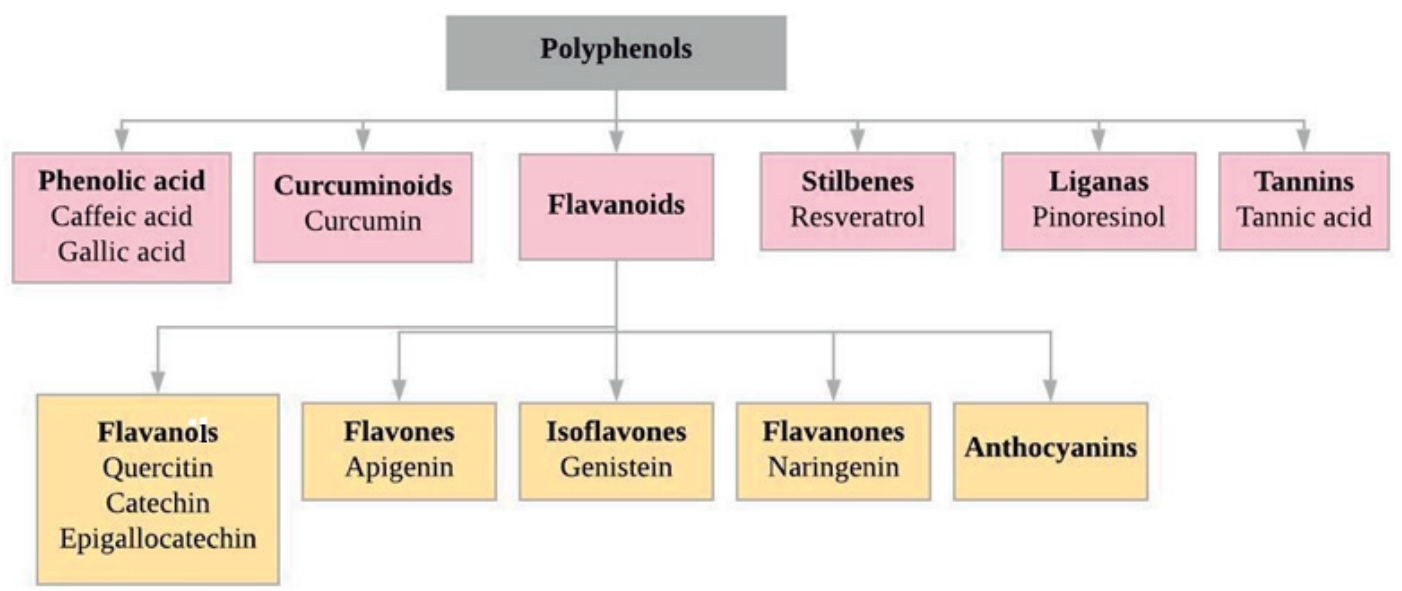

Source: Adapted from Mojzer et al. (2016).

Despite its numerous advantages, most phenolic compounds have limitations on bioavailability. Therefore different systems have been proposed as carriers of drugs and bioactive compounds, including, for example, polymeric nanoparticles, solid lipid nanoparticles, liposomes, nanogels, nanoemulsions, among others (FANTINI et al., 2015; CONTE et al., 2016) (Figure 3). Nanostructures have declared excellent performance as medication delivery vehicles, as in the studies covered in this review.

Figure 3 - Use of different nanostructures in the treatment of breast cancer.

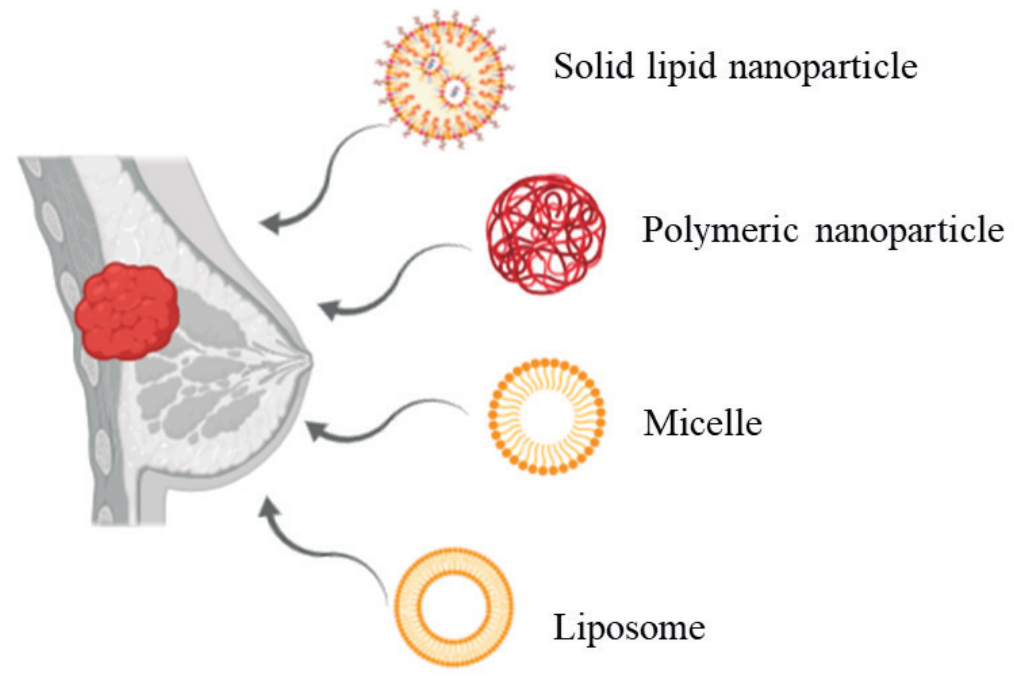

Source: Author's construction. 
Punica granatum, contains many phenolic compounds with high antioxidant and free radical scavenging activity, including flavonoids and tannins. Given its excellent antioxidant, anti-inflammatory, and antitumor potential, the fruit has been widely explored in the treatment of several diseases, including breast câncer (ROCHA et al., 2012; SHIRODE et al., 2015) (Table 1).

Table 1 - Studies were showing nanocarriers containing polyphenols present in pomegranate in the treatment of breast cancer in vitro tests.

\begin{tabular}{|c|c|c|c|}
\hline Nanocarrier & Compounds & Cell line & References \\
\hline PLGA - PEG Nanoparticles & $\begin{array}{c}\text { Pomegranate extract, } \\
\text { punicalagin and ellagic acid: }\end{array}$ & MCF-7 and Hs578T & Shirode et al., 2015 \\
\hline Solid lipid nanoparticles & Pomegranate extract & MCF-7 & Badawi et al., 2018 \\
\hline Silver nanoparticles & $\begin{array}{c}\text { Black-skinned pomegranate } \\
\text { polyphenols: }\end{array}$ & MCF-7 & Khorrami; Zarepour; Zarrabi, 2019 \\
\hline $\begin{array}{l}\text { Schizophyllan and chitin } \\
\text { nanoparticles }\end{array}$ & Ellagic acid & MCF-7 & Pirzadeh-Naeeni et al., 2020 \\
\hline
\end{tabular}

Source: Author's construction.

Shirode et al. (2015) produced PLGA/PEG nanoparticles containing pomegranate extract, punicalagin, and ellagic acid to evaluate their activity in MCF-7 and Hs578T breast ifere cell lines. This study showed particles of approximately $150 \mathrm{~nm}$. To assess the uptake of nanoparticles in vitro, cells were incubated for 5 minutes, 2 hours, 6 hours, and 24 hours and in the cell growth evaluation, it was observed that all pomegranate nanoparticles inhibited the growth of ifere cells in a significantly higher than the free extract in both cell lines. This corroborates the studies by Khorrami, Zarepour, Zarrabi (2019) and Badawi et al. (2018). They produced nanoparticles loaded with pomegranate extract showing more significant cell proliferation inhibition when compared to the free form, in addition to acting selectively against breast ifere cells:

Pirzadeh-Naeeni et al. (2020) used ellagic acid, the main antitumor compound of pomegranate loaded in schizophyllan and chitin nanoparticles, to investigate its effectiveness in the treatment of MCF-7 cells. The iferentete activity indicated that during the first three hours, the actions of eliminating free ellagic acid and nanoparticles containing ellagic acid increased the iferentete activity to $77 \%$ and $70 \%$, respectively. Cell viability assessment showed significant antiproliferation effects on MCF-7 cells, which improved at higher concentrations. These studies may suggest that nanoparticles using polyphenols iferent in pomegranate represent a method of choice for further investigations regarding breast ifere treatment using nanocarriers.

One of the most commonly found polyphenols in the literature in the treatment of breast ifere is curcumin. Extracted from the rhizome of Curcuma longa, it has been widely used in medicine due to its antitumor, iferentete, anti-inflammatory, healing, and antibacterial benefits (BANIK et al., 2017). Despite many advantages in the medical field, curcumin has low bioavailability when administered freely. This is one of the main reasons this bioactive compound needs a carrier capable of protecting and 
delivering it effectively, as is the case with nanostructures. Because it has a hydrophobic characteristic, curcumin is nanoencapsulated mainly in lipid nanoparticles and liposomes (FENG et al., 2017) (Table 2).

Table 2 - Studies were showing nanocarriers containing curcumin in the treatment of breast ifere in vitro trials.

\begin{tabular}{cccc}
\hline Nanocarrier & Compounds & Cell line & References \\
\hline Miristic acid-chitosan nanogels- & Curcumin & MDA-MB231 & Khosropanah et al., 2016 \\
Liposomes & Curcumin & $\begin{array}{c}\text { MCF-7 and } \\
\text { MDA-MB-468 }\end{array}$ & Kangarlou et al., 2017 \\
Tocotrienol nanoemulsion & Curcumin & MCF-7 & Steuber et al., 2016 \\
Nanoparticles PLGA/PEG & Curcumin & MCF-7 & Mirakabad et al., 2016 \\
Nanoparticles PLGA/PEG & Metformin and curcumin & T47D & Farajzadeh et al., 2018 \\
Nanocapsules & Curcumin and quercetin & MCF-7 & Ghayour et al., 2019 \\
Nanostructures of zinc & 3-Mercaptopropionic acid & MCF-7 & Ghaffari et al., 2019 \\
oxide-Bcyclodextrin & and curumin & Curcio et al., 2020 \\
Dextran nanoparticles & Methotrexate and curcumin & MCF-7 & Mansourizadeh et al., 2020 \\
\hline Apoferritin nanoparticles & Curcumin and quercetin & MCF-7 &
\end{tabular}

In the studies presented by Kangarlou et al. (2017) curcumin-loaded liposomes linked to homing peptides were produced for targeting integrin and neuropilin-1-mediated internalization in MCF-7 and MDA-MB-468 breast ifere lines. The particles were evaluated for cell viability using free curcumin and liposomes in both cell lines 24 hours. Liposomes showed a significant reduction in IC50 concerning free curcumin. They were indicating significant advantages of liposomes conjugated to peptides in the iferentete drugs to ifere cells.

Steuber et al. (2016) produced tocotrienol nanoemulsion to incorporate curcumin, evaluating the increased iferente efficacy against breast and ovarian carcinomas. The formulations exhibited a particle size of around $260 \mathrm{~nm}$, which remained unchanged for at least eight weeks. The nanoemulsion demonstrated the cytotoxic profile of MCF-7 cells in almost all concentrations tested, reaching a maximum cell death $(>90 \%)$ at $<30 \mu \mathrm{M}$ curcumin, notably suppressing the constitutive activation of the NF- $\kappa \mathrm{B}$ antibody and induced effector caspases, mediating ifere apoptosis.

Farajzadeh et al. (2018) assessed the level of hTERT iferentet in the T47D breast cell line, combining metformin and curcumin in ifere-sized PLGA/PEG nanoparticles of $202 \mathrm{~nm}$. In the analysis of cell cytotoxicity, curcumin and metformin were tested synergistically and separately for 72 hours and the metformin-curcumin nanoparticles. The non-encapsulated compounds showed a concentration-dependent cytotoxic effect, and the nanoparticles significantly interrupted the growth of ifere cells compared to free assets. The PCR assay showed that the nanoparticles suppressed the hTERT gene's iferentet more efficiently than the delivery of metformin and curcumin in the same concentrations, indicating a synergistic effect.

In iferen studies, Ghaffari et al. (2019) produced zinc oxide- $\beta$ cyclodextrin $(\beta C D)$ nanostructures functionalized by folic acid as a system for delivering curcumin. Cell viability assessment was carried out for 48 hours against breast ifere cells MDA-MB-231. The curcumin-loaded formulation exhibited a higher toxicity activity against the MDA-MB-231 cell line, with no effect on normal cells 
and better absorption of curcumin. Finally, it was observed that the structures conjugated with synthesized folic acid suppressed better size stability and high curcumin uptake for the cells.

To effectively deliver the chemotherapy methotrexate to breast ifere cells, Curcio et al. (2020) designed a nanocarrier system for the self-assembly of dextran and curcumin (DC). Nanoparticles with na average diameter of $290 \mathrm{~nm}$ were observed. In the cell viability test, MCF-7 breast ifere cells were used, which after $48 \mathrm{~h}$ of incubation with DC nanoparticles, cell viability was reduced by up to $47 \%$, suggesting the possibility of significantly reducing the dose of methotrexate for a treatment effective iferente with the combination of dextran-curcumin in nanocarriers.

Mansourizadeh et al. (2020) used apoferritin as a carrier in nanoparticles loaded with quercetin and curcumin, two phenolic compounds with antitumor activity, to evaluate their effect breast ifere cells. In the evaluation of cell apoptosis, the results showed that the nanoparticles produced more significant synergistic inhibition of the viability of MCF-7 cells than the administration of the same concentration of the free combination. Besides, apoferritin significantly reduced the cytotoxic effect on MCF10A breast iferente cells. Corroborating with studies carried out by Ghayour et al. (2018). They synthesized nanocapsules containing the polyphenols quercetin and curcumin in casein-based delivery systems to determine the cytotoxicity effect on human breast ifere cell line MCF-7. The nanoparticles showed a dose-dependent cell viability assessment. Even so, the nanoparticles containing the polyphenols showed more significant cell cytotoxicity than the free compounds.

Another natural product widely explored in research is green tea, with a chemical matrix full of polyphenols, especially catechins (YIANNAKOPOULOU, 2014). The literature discusses the role of green tea (Camellia sinensis) in preventing neoplasms by containing in its chemical matrix a variety of catechins responsible for its protective effect on DNA and in the induction of apoptosis in tumor cells (RAFIEIAN-KOPAEI; MOVAHEDI, 2017). Like other polyphenols, nanotechnology is used to efficiently protect and deliver assets, as shown in the following studies (MUKHERJEE et al., 2015) (Table 3).

Table 3 - Studies were showing nanocarriers containing green tea polyphenols in vitro experiments with breast ifere cells.

\begin{tabular}{|c|c|c|c|}
\hline Nanocarrier & Compounds & Cell line & References \\
\hline Liposomes & $\begin{array}{l}\text { Epigallocatechin gallate } \\
\text { (EGCG) and Paclitaxel: }\end{array}$ & MDA-MB-231 & Ramadass et al., 2015 \\
\hline PLGA-casein nanoparticles & $\begin{array}{l}\text { Epigallocatechin gallate } \\
\text { (EGCG) and Paclitaxel }\end{array}$ & MDA-MB-231 & Narayanan et al., 2015 \\
\hline Gold nanoparticles & Epigallocatechin-3-gallate- & MCF-7 & Mukherjee et al., 2015 \\
\hline Human ifer albumin nanoparticles & Morina and Epicatechin & MDA-MB-231 & Gosh et al., 2016 \\
\hline Solid lipid nanoparticles & Tea green extract & MCF-7 & Kulandaivelu, Mandal, 2016 \\
\hline Nanoparticles of lecithin-chitosan & Epicatechin & $\begin{array}{c}\text { MCF-7, MDA-MB-231, } \\
\text { MDA-MB-436 and SK-Br3 }\end{array}$ & Perez-Ruiz et al., 2018 \\
\hline Nanogels & Epigallocatechin and siRNA & MDA-MB-231 & Ding et al., 2018 \\
\hline Chitosan nanoparticles & Epigallocatechin-3-gallate- & MCF-7 & Liu et al., 2018 \\
\hline PLGA nanoparticles & $\begin{array}{l}\text { Epigallocatechin-3-gallate } \\
\text { (EGCG) decorated with folate }\end{array}$ & MDA-MB-231 & Kazi et al., 2020 \\
\hline
\end{tabular}


Ramadass et al. (2015) produced liposomes as co-delivery of epigallocatechin gallate and paclitaxel, a chemotherapeutic ifere used in breast ifere treatment ifere to inhibit target metalloproteinases. It has already been shown that MMP-2 and MMP-9 metalloproteinases are entirely expressed in cancerous tissues, and this has drawn a ifere attention due to their implications for tumor invasion and metastasis. Therefore, there are reports that epigallocatechin 3-gallate (EGCG) reduces the iferentet of MMP-2 and MMP-9. The cell viability showed high inhibition of metalloproteinases in the treatment with liposomes, with the activity of MMP-2 and MMP-9 being reduced by about $80 \%$ compared to the control. This study corroborates with that carried out by Narayanan et al. (2015). They also investigated EGCG and Paclitaxel's combination as na inhibitor of multiple signaling, focusing on the NF-kB pathway. It was encapsulated in a PLGA-casein nanoparticle targeted at breast ifere cell line MDA-MB-231 that sensitized paclitaxel-resistant breast ifere cells, inducing their apoptosis and inhibiting the activation of NF- $\mathrm{KB}$ by regulating the genes associated with angiogenesis and tumor metastasis.

In another study, Mukherjee et al. (2015) produced gold nanoparticles conjugated to EGCG and nanoparticles with green ifere assess toxicity against MCF-7 breast ifere cells. The nanoparticles showed toxic effects on MCF-7 cells, while they did not show any cytotoxic effects on the mice's hepatocytes used as controls. Besides, they limited the activation of NFr-B by almost $50 \%$ and triggered the onset of apoptosis. It also iferente significant cell uptake and good results in iferentete activity in vitro.

Ghosh et al. (2016) solubility enhancement of morin and epicatechin through encapsulation in an albumin based nanoparticulate system and their anticancer activity against the MDA-MB-468 breast cancer cell line. In in vitro toxicity assays, NPs-HSA-Mor and NPs-HSA-EC were able to destroy breast ifere cells by $42 \%$ and $26 \%$, respectively, compared to morine and epicatechin alone had more significant results ifere cells are highly toxic.

Perez-Ruiz et al. (2018) prepared lecithin-chitosan nanoparticles loaded with epicatechin (NPs-EC-LCT) by molecular self-assembly and to assess their cytotoxic potential against breast ifere cells. To compare the iferente activity of (-) - epicatechin and nanoparticles containing epicatechin, their cytotoxicity was evaluated in iferente breast ifere cell lines and non-cancer cells used as controls. It was observed that (-) - epicatechin showed no effect during $72 \mathrm{~h}$ of incubation. In contrast, NPs-EC-CLT generated the most significant inhibition of cell proliferation in all breast ifere cell lines and did not show cytotoxic effects to healthy cells, demonstrating that these nanoparticles have na inhibitory effect on human breast ifere cell line, in addition to presenting cell selectivity.

Resveratrol is a polyphenol that is iferen the class of stybenes. This compound has attracted attention due to its potential health benefits. It is widely found in plants such as grapes, plums, and peanuts (WANG et al., 2017; SUN et al., 2019). Its iferente, anti-inflammatory, iferentete, anti-aging, blood-sugar-lowering, and beneficial cardiovascular effects have been reported in many in vitro studies. Resveratrol iferent demonstrated its antiproliferative activity against tumor cells of various ifere types 
with resistance to multiple drugs (KO et al., 2017). Due to its low bioavailability, many studies have associated resveratrol with several nanocarriers as a iferen transport and delivery (WANG et al., 2017) (Table 4).

Table 4 - Studies were showing nanocarriers containing resveratrol in breast ifere cell assays.

\begin{tabular}{lccc}
\hline \multicolumn{1}{c}{ Nanocarrier } & Compounds & Cell line & References \\
\hline Liposomes & Paclitaxel and resveratrol- & MCF-7 & Meng et al., 2016 \\
\hline Solid lipid nanoparticles & Resveratrol & MDA-MB231 & Wang et al., 2017 \\
Nano-sponge based on cyclodextrin & Resveratrol and curcumin & MCF-7 & $\begin{array}{c}\text { Pushpalatha; Selvamuthukumar; } \\
\text { Gold nanoparticles }\end{array}$ \\
Oxidized mesoporous iferen nanoparticles & Resveratrol & MDA-MB-231 & Kilimozhi, 2019 \\
Mimetic lipoprotein nanoparticles & Resveratrol & MDA-MB-231 2019 \\
Nanoespheres & Resveratrol folate receptor & MCF-7 & Fan et al., 2019 \\
\hline
\end{tabular}

Source: Author's construction.

Meng et al. (2016) co-encapsulated a PEGylated Paclitaxel liposome combined with resveratrol as therapy for breast ifere treatment, using the MCF-7 line for in vitro studies. The average size of the liposomes, as observed by microscopy, was approximately $50 \mathrm{~nm}$. In assessing antitumor efficacy in MCF-7 cells, the free compounds showed less cytotoxicity. In contrast, the liposomes composed of resveratrol and paclitaxel showed significant cytotoxicity concerning the liposomes with the isolated compounds. Thus, indicating that the combined therapy potentially had a wide range of applications in ifere treatment.

Thipe et al. (2019) developed gold nanoparticles conjugated with biocompatible resveratrol (NPs-Res-Au) to explore the pro-apoptotic properties inherent in gold nanoparticles (NPs-Au) through synergistic antitumor characteristics of resveratrol in three types of ifere cells, including breast ifere. The particle size was in the range of $200 \mathrm{~nm}$, allowing na iferente penetration of NPs-Au through tumor cells. Thus, the cell viability test showed promising results from this combination, where a double antitumor effect was observed due to the composition of resveratrol and gold nanoparticles.

Pushpalatha, Selvamuthukumar, Kilimozhi (2019) aimed to design the transdermal co-delivery of curcumin and resveratrol using a nano-sponge-based cyclodextrin hydrogel. The nano-sponges containing curcumin had na average particle size of $490 \mathrm{~nm}$ and a load of $47.5 \%$. The nano-sponges with resveratrol had a size of $532 \mathrm{~nm}$ and loading of $48.8 \%$. The nanostructures showed a synergistic effect against MCF-7 cells in evaluating cytotoxicity in vitro showing high toxicity to the cells compared to the assessed assets in isolation and suggesting that this nanocarrier is na effective alternative against breast ifere cells.

Other phenolic compounds with antitumor effects are also associated with nanotechnology in breast ifere (Table 5). 
Table 5 - Studies were associating nanotechnology with iferente phenolic compounds in vitro experiments with breast ifere cells.

\begin{tabular}{|c|c|c|c|}
\hline Nanocarrier & Compounds & Cell line & References \\
\hline Gold nanoplaticles & Kaempferol & MCF-7 & Raghavan et al., 2015 \\
\hline Silver nanoparticles & Longan extract: & MCF-7 & Khan et al., 2018 \\
\hline Mesoporous ifere nanoparticles & Folic acid and quercitin & $\begin{array}{l}\text { MDA-MB231 } \\
\text { and MCF-7 }\end{array}$ & Sarkar et al., 2016 \\
\hline Solid lipid nanoparticle & Tannic acid and paclitaxel & MDA-MB-231 & Chowdhury et al., 2018 \\
\hline Nanopartícles & Quercitin & MCF-7 & Aghapour et al., 2018 \\
\hline PLGA Nanopartícles & Callistemon citrinus extract & $\begin{array}{l}\text { MCF-7, MCF-10 } \\
\text { and MDA-MB } 231\end{array}$ & Ahmed et al., 2019 \\
\hline Zinc oxide nanoparticles & Quercitin & MCF-7 & Sadhukhan et al., 2019 \\
\hline Silver nanoparticles & Vitis vinifera tannin & MCF-7 & Hashim et al., 2020 \\
\hline
\end{tabular}

Sarkar et al. (2016) synthesized mesoporous ifere nanoparticles labeled with folic acid and loaded with quercetin with na average $200 \mathrm{~nm}$ size. In the evaluation of cell uptake, nanoparticles labeled with folic acid showed greater uptake in MDA-MB-231 cells than unmarked nanoparticles. In the test to evaluate cell viability, nanoparticles containing quercetin and folic acid showed a reduction in cell viability by $50 \%$. In comparison, nanoparticles containing only quercitin had a $30 \%$ reduction, proving to be na effective therapeutic option against ifere cells breast.

Chowdhury et al. (2018) used tannic acid, a polyphenol belonging to the tannin class, together with the chemotherapeutic paclitaxel. With this, they developed nanoparticles of tannic acid-paclitaxel (NP-TAPs) to increase iferente effects in breast ifere cells MDA-MB-231, presenting nanoparticles of average size around $100 \mathrm{~nm}$. Cell uptake results were quite iferente with NP-TAPs compared to paclitaxel used alone. In the MTT test, the nanoparticles exhibited dose-dependent toxic effects against the MDA-MB-231 and MCF-7 strains. After 48 hours of treatment, there was a significant reduction in IC50 in NP-TAPs compared to chemotherapy used alone. From the results presented in this study, the authors suggest that tannic acid has na iferente iferente potential combined with chemotherapy drugs to treat breast ifere.

Ahmed et al. (2019) developed PLGA nanoparticles loaded with Callistemon citrinus, a plant known as Bottle Brush and rich in phenolic compounds, to assess its effects on the growth and proliferation of three types of breast ifere cell lines: MCF-7, MCF-10 a and MDA-MB 231. The nanoparticles had na average size of $250.7 \mathrm{~nm}$ with a storage period of 28 days at $4^{\circ} \mathrm{C}$ at $0.1 \mathrm{mg} / \mathrm{mL}-1$, a mixture of nanoformulation and $\mathrm{C}$. berberine citrinus induced the most iferen inhibition (33\%) of MDA-MB 231 cells. In contrast, the same concentration in the unformulated form induced only about $12 \%$ growth inhibition, suggesting that encapsulation resulted in na almost three-fold increase in nano-formed treatments' effectiveness.

Khan et al. (2016) used the fruits of Longan (Euphoria longana Lam.) Grown in Asia and which contain gallic acid, ellagic acid, and corilagin as main constituents. In this study, Longan's aqueous extract was associated with silver nanoparticles as na iferente ifere used in breast ifere cells. 
The cell viability test demonstrated a cytotoxic effect against MCF-7 cells of $88 \%$ at $100 \mu \mathrm{g} / \mathrm{mL}-1$ just as the iferentete evaluation by the DPPH method proved to be quite iferente, suggesting a useful alternative as a future treatment.

Aghapour et al. (2018) prepared quercetin nanoparticles to evaluate their effect on the MCF-7 strain cells. The nanoparticles had na average size of $84 \mathrm{~nm}$. When performing the MTT test with iferente formulation concentrations, a higher inhibition $(87 \%)$ was observed in the $72 \mathrm{~h}$ period in a dose-dependent manner. Besides, the nano-quercetin inhibitor's antiproliferative effect measured the progression of the cell cycle from phase G1 to phase S and apoptotic cell death in MCF-7 cells.

Finally, it can be observed that several phenolic compounds present in different fruits and plants cytotoxicity against breast cancer cells in the in vitro treatments performed, showing greater effectiveness when nanostructured in comparison with free compounds, resulting in the nanoencapsulated compounds having greater protection when exposed to external factors of degradation. In addition, some studies reported here brought results in which they point out that the nanostructures had an action on the modulation of gene and protein expression, suggesting a better targeting of the nanostructures in the treatment of cancer. However, it is necessary to carry out further studies using different experimental models that can ensure their effectiveness.

\section{CONCLUSION}

The present study reported the current research carried out regarding nanocarriers' production containing polyphenols in isolation or association with drugs for the treatment and prevention of breast cancer. Most of the polyphenols found in the studies have limitations in their bioavailability to the organism when included in the diet. In recent years, nanotechnology has gained significant prominence for developing carriers that can safely forward drugs and bioactive compounds, maintaining their chemical properties. We brought here different nanostructures for this purpose. Those that present significant results focus on liposomes and lipid nanoparticles associated with chemotherapy drugs and phenolic compounds to treat breast cancer cells in vitro studies. As well, curcumin and catechins were the most evident polyphenols in the studies, presenting satisfactory results. The studies, including nanotechnology for breast cancer treatment reported here, are of great interest to complement future research.

\section{REFERENCES}

AGHAPOUR, Fahimeh et al. Quercetin conjugated to silica nanoparticles inhibits tumor growth in MCF-7 breast cancer cell lines. Communications of Biochemical and Biophysical Research, v. 500, n. 4 , p. 860-865, 2018. 
AHMED, Rashid et al. Poly (lactic-co-glycolic acid) Nanoparticles Loaded with Callistemon citrinus Phenolics Exhibited Anticancer Properties against Three Breast Cancer Cell Lines. Journal of Food Quality, v. 2019, 2019.

AVTANSKI, Dimiter; PORETSKY, Leonid. Phyto-polyphenols as potential inhibitors of breast cancer metastasis. Molecular Medicine, v. 24, n. 1, p. 29, 2018.

BADAWI, Noha M. et al. Pomegranate extract-loaded solid lipid nanoparticles: design, optimization, and in vitro cytotoxicity study. International journal of nanomedicine, v. 13, p. 1313, 2018.

BANIK, Urmila et al. Curcumin: the spicy modulator of breast carcinogenesis. Journal of Experimental \& Clinical Cancer Research, v. 36, n. 1, p. 98, 2017.

CASSANO, Roberta et al. Preparation, characterization and in vitro evaluation of resveratrol-loaded nanospheres potentially useful for human breast carcinoma. Journal of Drug Delivery Science and Technology, v. 57, p. 101748, 2020.

CHOWDHURY, Pallabita et al. Nanoparticles of paclitaxel inspired by tannic acid for intensified anticancer effects in breast cancer cells. Journal of Colloid and Interface Science, v. 535, p. 133-148, 2019.

CONTE, R. et al. Polyphenols nanoencapsulation for therapeutic applications. Journal. Biomolecular Research Therapeutics, v. 5, n. 2, p. 139, 2016.

CURCIO, Manuela et al. Dextran-Curcumin Nanoparticles as a Methotrexate Delivery Vehicle: A Step Forward in Breast Cancer Combination Therapy. Pharmaceuticals, v. 13, n. 1, p. 2, 2020.

DAVATGARAN-TAGHIPOUR, Yasamin et al. Polyphenol nanoformulations for cancer therapy: experimental evidence and clinical perspective. International Journal of Nanomedicine, v. 12, p. 2689, 2017.

DING, Jie et al. "Stealth and Fully-Laden" Drug Carriers: Self-Assembled Nanogels Encapsulated with Epigallocatechin Gallate and siRNA for Drug-Resistant Breast Cancer Therapy. ACS Applied Materials \& Interfaces, v. 10, n. 12, p. 9938-9948, 2018. 
FAN, Conghui et al. Resveratrol loaded oxidized mesoporous carbon nanoparticles: A promising tool to treat triple negative breast cancer. Biochemical and Biophysical Research Communications, v. 519, n. 2, p. 378-384, 2019.

FANTINI, Massimo et al. Efeitos antitumorais in vitro e in vivo de combinações de polifenóis, ou polifenóis e drogas anticâncer: perspectivas no tratamento do câncer. Jornal Internacional de Ciências Moleculares, v. 16, n. 5, p. 9236-9282, 2015.

FARAJZADEH, Raana et al. Nano-encapsulated metformin-curcumin in PLGA/PEG inhibits synergistically growth and hTERT gene expression in human breast cancer cells. Artificial Cells, Nanomedicine and Biotechnology, v. 46, n. 5, p. 917-925, 2018.

FENG, Ting et al. Liposomal curcumin and its application in cancer. International journal of nanomedicine, v. 12, p. 6027-6044, 2017.

GHAFFARI, Seyed-Behnam et al. Flower-like curcumin-loaded folic acid-conjugated ZnO-MPA- $\beta$ cyclodextrin nanostructures enhanced anticancer activity and cellular uptake of curcumin in breast cancer cells. Materials Science and Engineering: C, v. 103, p. 109827, 2019.

GHAYOUR, Nazanin et al. Nanoencapsulation of quercetin and curcumin in casein-based delivery systems. Food hydrocolloids, v. 87, p. 394-403, 2019.

GHOSH, Pooja et al. Solubility enhancement of morin and epicatechin through encapsulation in an albumin based nanoparticulate system and their anticancer activity against the MDA-MB-468 breast cancer cell line. RSC Advances, v. 6, n. 103, p. 101415-101429, 2016.

HASHIM, Nornisrina et al. Green mode synthesis of silver nanoparticles using Vitis vinifera's tannin and screening its antimicrobial activity/apoptotic potential versus cancer cells. Materials Today Communications, v. 25, p. 101511, 2020.

INCA - José Alencar Gomes da Silva National Cancer Institute. The situation of breast cancer in Brazil: synthesis of data from information systems. José Alencar Gomes da Silva National Cancer Institute. - Rio de Janeiro. Accessed in: November/2020. 
KANGARLOU, Sogol et al. Curcumin-loaded nanoliposomes linked to homing peptides for integrin targeting and neuropilin-1-mediated internalization. Pharmaceutical Biology, v. 55, n. 1, p. 277-285, 2017.

KAZI, Julekha et al. Folate decorated epigallocatechin-3-gallate (EGCG) loaded PLGA nanoparticles; in-vitro and in-vivo targeting efficacy against MDA-MB-231 tumor xenograft. International Journal of Pharmaceutics, v. 585, p. 119449, 2020.

KHAN, Arif Ullah et al. An eco-benign synthesis of AgNPs using aqueous extract of Longan fruit peel: Antiproliferative response against human breast cancer cell line MCF-7, antioxidant and photocatalytic deprivation of methylene blue. Journal of Photochemistry and Photobiology B: Biology, v. 183 , p. $367-373,2018$.

KHAN, Haoon et al. Flavonoid nanoparticles in cancer: treatment, prevention and clinical perspectives. In: Seminars on Cancer Biology. Academic press, 2019.

KHORRAMI, Sadegh; ZAREPOUR, Atefeh; ZARRABI, Ali. Green synthesis of silver nanoparticles at a low temperature at an accelerated rate, with exclusive elimination of DPPH radicals and selective cytotoxicity against the MCF-7 and BT-20 tumor cell lines. Biotechnology Reports, v. 24, p. e00393, 2019.

KHOSROPANAH, Mohammad Hossein et al. Analysis of the antiproliferative effects of curcumin and nanocurcumin in MDA-MB231 as a breast cancer cell line. Iranian Journal of Pharmaceutical Research: IJPR, v. 15, n. 1, p. 231, 2016.

KO, Jeong-Hyeon et al. The role of resveratrol in cancer therapy. International Journal of Molecular Sciences, v. 18, n. 12, p. 2589, 2017.

KOLAK, Agnieszka et al. Prevenção primária e secundária do câncer de mama. Ann Agric Environ Med, v. 24, n. 4, p. 549-553, 2017.

KULANDAIVELU, Karikalan; MANDAL, Abul. Positive regulation of biochemical parameters by solid lipid nanoparticles encapsulated with tea polyphenol under in vitro and in vivo conditions. IET Nanobiotechnology, v. 10, n. 6, p. 419-424, 2016.

LIU, Yingyi et al. Preparation of chitosan-Epigallocatechin-3-O-gallate nanoparticles and their inhibitory effect on the growth of breast cancer cells. Journal of Innovative Optical Health Sciences, v. 11, n. 04, p. 1850018, 2018. 
MANSOURIZADEH, Fariba et al. Efficient synergistic combination effect of Quercetin with Curcumin on breast cancer cell apoptosis through their loading into Apo ferritin cavity. Colloids and Surfaces B: Biointerfaces, v. 191, p. 110982, 2020.

MENG, Jie et al. Combination therapy using co-encapsulated resveratrol and paclitaxel in liposomes for drug resistance reversal in breast cancer cells in vivo. Scientific Reports, v. 6, p. 22390, 2016.

MIRAKABAD, Fatemeh Sadat et al. A comparison between the cytotoxic effects of pure curcumin and PLGA-PEG nanoparticles loaded with curcumin in the MCF-7 human breast cancer cell line. Artificial Cells, Nanomedicine and Biotechnology, v. 44, n. 1, p. 423-430, 2016.

MOJZER, Eva et al. Polyphenols: Extraction methods, antioxidative action, bioavailability and anticarcinogenic effects. Molecules, v. 21, n. 7, p. 901, 2016.

MUKHERJEE, Sudeshna et al. Gold-conjugated green tea nanoparticles for enhanced anti-tumor activities and hepatoprotection-Synthesis, characterization and in vitro evaluation. The Journal of Nutritional Biochemistry, v. 26, n. 11, p. 1283-1297, 2015.

NARAYANAN, Sreeja et al. Sequential release of epigallocatechin gallate and paclitaxel from PLGA-casein core/shell nanoparticles sensitizes drug-resistant breast cancer cells. Nanomedicine: Nanotechnology, Biology and Medicine, v. 11, n. 6, p. 1399-1406, 2015.

PEREZ-RUIZ, Adriana Guadalupe et al. Lecithin-chitosan-TPGS nanoparticles as nanocarriers of (-)-epicatechin enhanced its anticancer activity in breast cancer cells. RSC Advances, v. 8, n. 61, p. 34773-34782, 2018.

PIRZADEH-NAEENI, Shirin et al. A comparative study on schizophyllan and chitin nanoparticles for ellagic acid delivery in treating breast cancer. International Journal of Biological Macromolecules, v. 144, p. 380-388, 2020.

POONIA, Neelam et al. Resveratrol-loaded folate targeted lipoprotein-mimetic nanoparticles with improved cytotoxicity, antioxidant activity and pharmacokinetic profile. Materials Science and Engineering: C, v. 144, p. 111016, 2020. 
PUSHPALATHA, R.; SELVAMUTHUKUMAR, S.; KILIMOZHI, D. Cyclodextrin nanosponge based hydrogel for the transdermal co-delivery of curcumin and resveratrol: Development, optimization, in vitro and ex vivo evaluation. Journal of Drug Delivery Science and Technology, v. 52, p. 55-64, 2019.

RAFIEIAN-KOPAEI, Mahmoud; MOVAHEDI, Mino. Breast cancer chemopreventive and chemotherapeutic effects of Camellia Sinensis (green tea): an updated review. Electronic Physician, v. 9, n. 2, p. 3838, 2017.

RAGHAVAN, Bhuvanasree et al. Kaempferol mediated synthesis of gold nanoparticles and their cytotoxic effects on MCF-7 cancer cell line. Process Biochemistry, v. 50, n. 11, p. 1966-1976, 2015.

RAMADASS, Satiesh Kumar et al. Paclitaxel/epigallocatechin gallate coloaded liposome: a synergistic delivery to control the invasiveness of MDA-MB-231 breast cancer cells. Colloids and Surfaces B: Biointerfaces, v. 125, p. 65-72, 2015.

RAMLJAK, D. et al. Pentameric procyanidin from Theobroma cacao selectively inhibits growth of human breast cancer cells. Molecular Cancer Therapeutics, v. 4, n. 4, p. 537-546, 2005.

ROCHA, Ana et al. Pomegranate juice and specific components inhibit cell and molecular processes critical for metastasis of breast cancer. Breast Cancer Research and Treatment, v. 136, n. 3, p. 647-658, 2012.

SADHUKHAN, Pritam et al. Targeted distribution of quercetin via $\mathrm{pH}$-responsive zinc oxide nanoparticles for breast cancer therapy. Materials Science and Engineering, v. 100, p. 129-140, 2019.

SANTOS, Ana Cláudia et al. Nanotechnology-based formulations for resveratrol delivery: Effects on resveratrol in vivo bioavailability and bioactivity. Colloids and Surfaces B: Biointerfaces, v. 180, p. 127-140, 2019.

SARKAR, Abhijit et al. Targeted delivery of quercetin loaded mesoporous silica nanoparticles to the breast cancer cells. Biochimica et Biophysica Acta (BBA)-General Subjects, v. 1860, n. 10, p. 2065-2075, 2016.

SHIRODE, Amit B. et al. Nanoencapsulation of pomegranate bioactive compounds for breast cancer chemoprevention. International Journal of Nanomedicine, v. 10, p. 475-484, 2015. 
SILVA, Claudia et al. Selective pro-apoptotic and antimigratory effects of polyphenol complex catechin: lysine 1: 2 in breast, pancreatic and colorectal cancer cell lines. European Journal of Pharmacology, v. 859, p. 172533, 2019.

STEUBER, Nelson et al. Tocotrienol nanoemulsion platform of curcumin elicit elevated apoptosis and augmentation of anticancer efficacy against breast and ovarian carcinomas. International Journal of Molecular Sciences, v. 17, n. 11, p. 1792, 2016.

SUN, Yang et al. O resveratrol inibe a migração e metástase do câncer de mama humano MDA-MB-231 ao reverter a transição epitelial-mesenquimal induzida por TGF- $\beta 1$. Molecules , v. 24, n. 6 , p. 1131, 2019.

THIPE, Velaphi et al. Development of resveratrol-conjugated gold nanoparticles: Interrelationship of increased resveratrol corona on anti-tumor efficacy against breast, pancreatic and prostate cancers. International Journal of Nanomedicine, v. 14, p. 4413, 2019.

WANG, Wenrui et al. Anticancer effects of resveratrol-loaded solid lipid nanoparticles on human breast cancer cells. Molecules, v. 22, n. 11, p. 1814, 2017.

YIANNAKOPOULOU, Eugenia C. Interaction of green tea catechins with breast cancer endocrine treatment: a systematic review. Pharmacology, v. 94, n. 5-6, p. 245-248, 2014. 
